\title{
Investigating the Framework for Examining the Factors Influencing Vocational Education and Training (VET) as the Crucial Factor of Self-Employment and Entrepreneurship Development ${ }^{1}$
}

\author{
Muhammad Kamran*
}

The main purpose of this study is to analyze the existing work of researchers in respect of effectiveness of vocational education and training (VET). Vocational education and training enhances human potentials and diversifies peoples' choices in order to promote self-employment and entrepreneurship development. Most of the vocational education students contribute to entrepreneurship programs at some point during their vocational education path. In this study, the researcher has discussed the impact of Curriculum Revision and Vocational Entrepreneurship Education, Need Based Training, Interrelation with Industry, Employability, Assessment and Examination, Physical Resources and Trainee Selection on VET effectiveness. Human Capital Theory, which emphasizes the contribution of education and training to individual as well as organization productivity (Becker 1962), is related to the occupational structure of the labor market and the labor market institutions. Most of the researchers have linked vocational education and training with Human Capital Theory. So, it is necessary to study the existing work of researchers in context of vocational education and training so that VET effectiveness can be increased, which is considered as an important factor of development in any country.

Keywords: vocational education and training, entrepreneurship, effectiveness of vocational education and training.

Submitted: 20.06.2015 | Accepted: 22.09.2015

\section{Analiza ram badania czynników wpływających na kształcenie i szkolenie zawodowe jako zasadniczy element rozwoju samozatrudnienia i przedsiębiorczości}

Głównym celem artykułu jest analiza dotychczasowych prac naukowych poświęconych skuteczności ksztatcenia $i$ szkolenia zawodowego. Ksztatcenie $i$ szkolenie zawodowe pozwala na zwiększenie potencjatu jednostek $i$ umożliwia dywersyfikację decyzji, prowadzac do rozwoju samozatrudnienia i przedsiębiorczości. Większość osób ksztatcących się zawodowo wnosi wktad w programy przedsiębiorczości na pewnym etapie swojego ksztatcenia. W artykule badacz zaprezentowat wptyw weryfikacji programu nauczania $i$ ksztatcenia zawodowego $w$ zakresie przedsiębiorczości, szkolenia w zależności od potrzeb, wzajemnych powiązań z przemystem, umiejętności przystosowania zawodowego, ocen i egzaminów, zasobów fizycznych i doboru uczestników szkolenia na skuteczność ksztatcenia i szkolenia zawodowego. Struktury zawodowej rynku pracy i jego instytucji dotyczy teoria kapitału ludzkiego, kładaca nacisk na możliwość podwyższenia wydajności indywidualnej i organizacyjnej poprzez kształcenie i szko-

\footnotetext{
Muhammad Kamran - Faculty of Management, University of Warsaw, Poland. Adres do korespondencji: author's email: m_kamran@comsats.edu.pk.
} 
lenie (Becker 1962). Większość badaczy wiąże ksztatcenie i szkolenie zawodowe z ta właśnie teoria. W celu zwiększenia skuteczności tego rodzaju ksztatcenia, uznawanego za istotny czynnik rozwoju w każdym kraju, należy zatem przeprowadzić analize dotychczasowych prac naukowych w tym zakresie.

Słowa kluczowe: kształcenie i szkolenie zawodowe, przedsiębiorczość, skuteczność kształcenia i szkolenia zawodowego.

Nadesłany: 20.06.2015 | Zaakceptowany do druku: 22.09.2015

JEL: M53

\section{Introduction}

Entrepreneurs or changes towards self-employment are becoming an important element of economic growth and development (Briga, 1996). Vocational education and training enhances human potentials and diversifies peoples' choices in order to promote self-employment and entrepreneurship development (Ansari, 2013). To equip the VET students for self-employment on graduation, appropriate implementation of entrepreneurship education is a necessary tool (Edmond, 2014). Vocational education is about personal development, as well as social change and occupational mobility (Margriet et al., 2014). Vocational Education and Training (VET) may be considered as human development and capabilities approach (McGrath, 2012). Human Capital Theory, which emphasizes the contribution of education and training to individual as well as organization productivity (Becker, 1962), is related to the occupational structure of the labor market and the labor market institutions. Middieton et al. (1993) strongly emphasize that Human Capital Theory provides a fruitful framework for evaluating training especially in the vocational education and training context. According to Schultz (1961), a development in human activities in which a person shows himself as more useful and more productive according to the changes in the economy is known as human capital formation. Becker (1975) and Mincer (1974) stated that vocational training and skills development are considered as a main source of human capital from which earning of life and indirect positive benefits can be gained for an individual. Nilsson (2010) also relates Human Capital Theory with vocational education and training because vocational education and training is considered as a major factor to increase the economic growth and labor productivity.

The first purpose of Vocational Education and Training (VET) is to meet the demands of the labor market to equip the students with the theoretical and practical tools needed to function within their various occupations (Clarke \& Winch, 2007; Westerhuis, 2007). In several countries, VET colleges serve both the purpose of preparing students for working life and the purpose of preparing them to face the challenges of the labor market (Margriet et al., 2014). Since competence-based education and training is increasingly widespread, the focus of VET shifted towards the skill sets necessary to function in a specific work environment (Argüelles \& Gonczi, 2000; Brockmann et al., 2008; Cedefop, 2010). VET colleges are responsible for meeting the demand of the labor market for which they should work in close collaboration with companies (Margriet et al., 2014). Another purpose of VET is to meet an increasing number of requirements regarding the organization of programs (Clarke \& Winch, 2007; Westerhuis, 2007) and the professional development of VET teaching (Shaw, 1999; Stanton \& Bailey, 2001; Cort et al., 2004). Sower (1971) also emphasizes that vocational/technical education is mainly associated with the people and their work and vocational education is the main source of organizing the people for work.

The second aim of VET is to improve the national educational performance (Margriet et al., 2014). To cope with the international competition, quality vocational education and training (VET) programs have a direct link with increasing 
work efficiency and productivity (Cornford, 1999). Vocational education is perceived as an instrument to produce more productive workforce to increase the prosperity of a nation (Cullen, 1997). Many studies found that young people in countries with strong initial vocational education and training (VET) systems fare better than their counterparts in countries that provide mainly general education (e.g. Breen, 2005; Brzinsky-Fay, 2007; De Graaf \& van Zenderen, 2013; Müller \& Gangl, 2003; Scherer, 2005; Wolbers, 2007). So, it is necessary to take some important steps to improve national educational performance by improving the quality of VET.

The third aim of VET is considered as a source of decreasing the poverty and unemployment from the society (McGrath, 2012). Tilak (2002) stated that vocational training was considered to provide a solution to problems of education in the developing countries' economies. Moreover, VET refers to education and training that prepares people for employment and makes them more productive in various economic sectors (Finch \& Crunkilton, 1999). VET enhances human potentials and diversifies peoples' choices in order to promote selfemployment and entrepreneurship development. It is perceived that VET plays an important role for social development (UNESCO, 2004; Jallah, 2004) and has a significant impact on the alleviation of poverty in the society. The contribution of entrepreneurship education in VET programs is also helpful for poverty alleviation from the society (Edmond, 2014).

Entrepreneurship education is more applicable than ever before (Fayolle, 2010; Matlay, 2008), especially in the vocational education and training context (Jossberger et al., 2010; Avis, 2012). Work based learning is an essential part of vocational learning in which interrelation with business community naturally relates to entrepreneurial learning (Jarvi, 2012). There is close cooperation between vocational schools and enterprises in Europe, but the gap still exists in entrepreneurship education (Jarvi, 2012). Unfortunately, very little research has been conducted on the education of entrepreneurship, in particular on vocational education (Pihie \& Bagheri, 2010), and there is dire need of time to include vocational entrepreneurship education in the vocational curriculum (Jarvi, 2012).
Entrepreneurship education is a necessary tool for self-employment of VET students (Edmond, 2014).

Keeping in view the above discussion, it is clear that vocational education and training has a significant impact on satisfying the demand of the labor market. Moreover, VET is also considered to improve the national educational performance. Furthermore, VET is considered to be a solution for unemployment and poverty alleviation. So, there is a dire need of working to improve the effectiveness of VET. In this regard, it is necessary to study the existing work on VET so that suggestions are made to improve the effectiveness of VET which is a considerable need of today. In the present scenario, promotion of vocational education and training is considered to be a key aspect of any development initiative that intends to improve socio-economic well-being, generate jobs and eliminate poverty (Grierson \& Young, 2002).

\subsection{Purpose of the Study}

The main purpose of this study is to analyze the existing work of researchers in respect of effectiveness of vocational education and training. In this study, the researcher has discussed the impact of Need Based Training, Interrelation with Industry, Employability, Curriculum Revision and Vocational Entrepreneurship Education, Assessment and Examination, Physical Resources and Trainee Selection on VET effectiveness. Human Capital Theory, which emphasizes the contribution of education and training to individual as well as organization productivity (Becker, 1962), is related to the occupational structure of the labor market and the labor market institutions. Most of the researchers have linked vocational education and training with Human Capital Theory. So, it is necessary to study the existing work of researchers in the context of vocational education and training so that VET effectiveness can be increased, which is considered as an important factor of development in any country.

\subsection{Scope of the Study}

The basic scope of this study is to analyze the existing work of researchers in respect of effectiveness of vocational education and training. In this study, the researcher has discussed the impact of Need Based 
Training, Interrelation with Industry, Employability, Curriculum Revision and Vocational Entrepreneurship Education, Assessment and Examination, Physical Resources and Trainee Selection on VET effectiveness. Most of the researchers have linked vocational education and training with Human Capital Theory. Practically, vocational education and training is one of important factors of human capital which plays an important role in the development of a country.

\subsection{Rationale of the Study}

The author has made an effort to understand the existing work of different scholars on VET and examine the existing work scenario so that effectiveness of VET can be increased. The study would be beneficial not only for trainees, trainers and training institutes but it will also be helpful to fulfill the demand for skilled workers in the labor market.

\subsection{Limitations of the Study}

The author has made an effort to work based on the existing literature towards the effectiveness of VET. The author has mainly analyzed important factors that can play an important role towards the effectiveness of VET but there are a number of more factors that can also be discussed in this context.

\section{Literature Review}

Recently, several scholars have pointed out that the notion of a simplified dichotomy between general and specific skills, as conceptualized within the framework of Asset Theory adopted in the Varieties of Capitalism approach, lacks analytical rigor in capturing differences in the skills provided by the education and training system (Busemeyer, 2009; Busemeyer \& Trampusch, 2012; Iversen \& Stephens, 2008; Streeck, 2012). Whilst in the Asset Theory, the portability of skills is a property of their content, i.e. substantive breath, portability in Human Capital Theory as defined by Becker (1962) is related to the occupational structure of the labor market and the labor market institutions. Human Resource Development (HRD) is a process in which human efficiency can be improved through personal training and development to increase the performance (Swan- son, 1995). Training is one of important activities of human resource development. Training is a group of activities that is helpful for a worker to perform his job more effectively (Moskowitz, 2008). Vocational education and training is one of the forms of training. Vocational training and learning has a significant impact on the development of a group and an individual (Jamshidi \& Jamshidi, 2012).

In the economic growth of any country, vocational training is one of significant factors (Moldovan, 2012). Vocational education and training offers skills to people for a specific job. VET is normally linked to physical and hands on activities related to a particular vocation, trade or occupation. VET enhances human potentials and diversifies peoples' choices in order to promote self-employment and entrepreneurship development (Ansari, 2013). It is perceived that VET plays an important role for social development and sustainable citizenship (UNESCO, 2004; Jallah, 2004). In the context of China's current rapid economic growth, the latest five-year plan (2011-2015) calls for an increase in high-skilled work as a way of raising living standards (Jing Xu, 2011). Technical and vocational education is considered as a valuable policy issue in developing countries (King, 2009; Palmer, 2009). Karbasioun (2005) argued that the trained workforce is the key focus of attention in most of the development programs. Asian countries put a strong emphasis on vocational education in formal and non-formal educations system. This is the reason why the world has observed economic development of the Asian Tigers. The main reason for this speedy growth is heavy investment in human capital. These countries put a special emphasis on the development of labor productivity, which was productive for laborers (Mustafa et al., 2005).

Vocational education and training plays an important role in poverty alleviation from the society and is a source of training for employability (Powell, 2012). VET provides a solution to unemployment and alleviates poverty in Africa (McGrath, 2012). VET has a major role in the growth of the economy in Africa (McGrath, 2011). Moreover, VET is helpful in removing discrimination between urban and poor populations. Usually, rural people are not equipped with the education pro- 
vided by elite education systems and the unemployment rate is much higher among rural people than urban people. Carmen (2012) also emphasizes that vocational training is helpful in lessening the poverty and unemployment. The main reason for unemployment in South Africa is skills shortage (Allais, 2012). Skills development and training are necessary for economic growth (Mustafa et al., 2005). The rate of return can be increased by employment of skilled workers (Booth et al., 1996). The main purpose of VET is to provide the skills that should be applicable in the workplace and it is evident that VET has a positive impact on productivity and economic growth (Nilsson, 2010). In the European context, VET is considered as a major tool in the transformation of the European economy (Baum, 2002; Budría \& TelhadoPereira, 2009; Mupimpila \& Narayana, 2009; Spielhofer \& Sims, 2004). The contribution of entrepreneurship education in VET programs is also helpful in poverty alleviation from the society (Edmond, 2014).

Keeping in view the above discussion in the literature review, it can be seen that vocational education and training is one of important activities of human resource development. VET does not only provide skills to the workers but it also has a significant impact on the economy. VET also plays a significant role in poverty alleviation and is a source of training for employment. Vocational training and development is considered as a solution to unemployment and organizations are spending huge amount of money on VET in private and public sectors. The researchers believe that VET can solve the workplace problems and is a source of skills and knowledge of the labor force. Because of this fact, this is the dire need of time to work on the factors that are helpful in promoting quality vocational education and training.

\subsection{Vocational Education and Training Dimensions}

Vocational education and training has a number of dimensions that have a significant impact on the evaluation of training (Aldrich, 2002). Keeping in view the research conducted on vocational education and training, this research explains the most significant dimensions of VET: Curriculum Revision and Vocational Entrepre- neurship Education, Need Based Training, Interrelation with Industry, Employability, Assessment and Examination, Physical Resources and Trainee Selection. All these dimensions have a clear influence on the performance and results of training programs.

\subsubsection{Curriculum Revision and Vocational Entrepreneurship Education}

Entrepreneurship education is more applicable than ever before (Fayolle, 2010; Matlay, 2008), especially in the vocational education and training context (Jossberger et al., 2010; Avis, 2012). There is massive growth in entrepreneurship education programs as it is recognized by businesses and governments that entrepreneurship is a useful tool for the market economy (Jones, 2010). Curriculum development is a repetitive process and has a significant impact on a number of stakeholders (Van den Akker, 2003). A high quality curriculum helps teachers employ active learning processes (Cornford, 1999). To meet the demand of the industry, a VET curriculum should incorporate skills needed by employers (Vogtenhuber, 2014).

A revision of contents of courses is essential to promote learning (Badaqir et al., 2011). To meet the challenges of industrial growth and expansion, there should be a continuous revision of curricula of polytechnic institutes (Bakah et al., 2011). Vocational students should be equipped with the skills that are required at the workplace and these skills should be derived from the curriculum (Virtanen et al., 2014). Unfortunately, less attention has been paid to reviewing curriculum structures or assessment practices (Oxtoby, 1997) and there is dire need of time to include vocational entrepreneurship education in the vocational curriculum (Jarvi, 2012).

\subsubsection{Assessment and Examination}

Assessment has a great impact on the quality of students' learning (Chalmers \& Fuller, 1996; Jordan, 1989; Mahendran, 1997; Scott, 1997). No course evaluation should be complete without a proper assessment system (Jordan, 1989). Chalmers \& Fuller (1996) have claimed that grading and learning are the two main functions of assessment. In order to promote learning, there should be a review of the assessment methods (Badaqir et al., 2011). 
In order to examine the skills and knowledge at work, students' learning should be examined properly and learning should be followed by an assessment (Virtanen et al., 2014). The Program for International Student Assessment (PISA), an international assessment program, has been focused on standards of literacy in vocational education (OECD, 2001). In this dimension, the researcher will measure the method of examination, examination environment and graduating criteria.

\subsubsection{Selection of Trainees}

Selection of trainees always has a significant impact on the effectiveness of training. According to Enkuzena \& Kliedere (2011), trainees should be selected on the basis of their motivation for learning. Training environment plays an important role in the effectiveness of training (Tassmeer \& Harris, 1992). Russ-Eft (2002) has discussed a model which shows characteristics of training, indicating that especially trainee selection has a crucial impact on the training program. In this dimension, the researcher will measure the competence of trainees registered in the training program, process of selection for the trainees and entry qualification of trainees in the training program.

\subsubsection{Physical Resources}

Training facilities and equipment used in training laboratories have become a substantial factor in the vocational training programs (Farmer et al., 2004). There is no concept of effective vocational training without suitable provision of learning facilities (Puyate, 2004). The teachers admit that there exists modern equipment in the industry but polytechnic institutes are lacking in providing the latest equipment (Bakah et al., 2011). Unfortunately, most of the equipment and tools used in the polytechnics are damaged and are not replaced by the institutes (Puyate, 2006). The researcher will measures the information about interrelationship among class rooms, services provided by the institution, number of class rooms and laboratories, lightening and ventilation system, maintenance of building and services, safety features, utilization of space for class rooms and laboratories and provision of supportive equipment like multimedia, projectors etc.

\subsubsection{Interrelation with Industry}

The interrelation of vocational education and training with the industry is considered as a necessary condition for ensuring the success of VET programs (Akomaning et al., 2011). A link with the industry normally refers to the placement of trainees in the workplace (Choy \& Haukka, 2009). The recent learning theories describe the integration of learning and workplace and these should be connected to each other from the early stages of education (e.g. Griffiths \& Guile, 2003; Tynjälä, 2008, 2009). Educational institutes and industry linkage leads to successful internships (Divine et al., 2007). Without involvement of employers in delivering vocational training, vocational education is unreliable and unsustainable (Chen, 2006). There should be at least a six month internship outside the vocational institute to meet the degree requirement (Virtanen et al., 2014). It is a fact that there should be close interrelation between industries and vocational training institutes (Guile \& Griffiths, 2003). Unfortunately, the distance between the workplace and institutes has increased and there is a dire need for them to be brought closer together (Allais, 2012).

\subsubsection{Government Support / Financial Support}

The government's attitude towards education is always considered as an important feature in the education system. It is the core responsibility of the government to implement the national education program in an effective way (Puyate, 2008). From the international comparative perspective, governments regard VET as an important factor in the positioning of their countries (Shaw, 1999; OECD, 2009; Leney \& Green, 2005). It is necessary for the government to provide proper funds to VET schools to run the vocational education programs effectively (Puyate, 2008).

\subsubsection{Employability}

The institute should also assess trainees on their skills and knowledge acquired at work (Virtanen et al., 2014). In vocational education and training, the employer's appreciation for the trainees is highly important (Margriet et al., 2014). The rate of unemployment is used to assess the quality of VET systems (European Parliament and Council, 2009). The voca- 
tional education and training system has been described as "having the ambition to become employer led" (Sung, 2010).

\section{Research Methodology}

In this section, the author gives details about the systematic review, research questions, research objective, research design and theoretical framework of the study.

\subsection{Systematic Review}

Due to the conflicting nature of the discipline of management, there is a lack of thoroughness and real investigation owing to unsystematic reviews of previous studies (Tranfield et al., 2003). Therefore, it is necessary to make a domain analysis of critical review of the relevant literature. This structure is consistent with Schaap et al. (2012), Iqbal et al. (2014) and also partly similar to the one that Ponis et al. (2009) used. This process of systematic review is conducted in four phases. First, the author has formulated general keywords for the selection of literature. Second, a thorough analysis is performed based on key publications to elaborate general keywords. Additionally, keywords for synonyms are also formulated. In the third stage, literature is explored in two databases: ABS and ISI indexed journals. Finally, sample filtering is done based on availability and relevance of the relevant material.

In this research, the author focused on quality journals listed in the academic journal quality guide of the Social Science Citation Index (SSCI) and Association of Business Schools (ABS). The advanced search options are also used to produce relevant results from the homepage of each journal. As the first step, the main search terms of "VET", "VET effectiveness" and "factors influencing VET" are applied. The general keywords are: vocational education, vocational training, factors influencing VET, Need Based Training, Interrelation with Industry, Employability, Curriculum Revision and Vocational Entrepreneurship Education, Assessment and Examination, Physical Resources, Trainee Selection and vocational training effectiveness. After that, key search terms were used for searching inside the results.

The author used the truncation symbol to all search terms to the full text. The process produced 235 articles, then skim read- ing (rapid scanning of the entire article) is applied to select the most relevant ones (Thomas, 2004). Concentrating more on the concepts of VET, the researcher selected the most relevant articles. A total of 105 articles, published in 20 journals, met the criteria. With regard to periodization, the author focused more on studies published in 2000 and onwards. The author also uses studies published before 2000 .

\section{Conclusion}

The above mentioned review clearly reveals that vocational education and training is one of important activities of human resource development. VET also plays a significant role in poverty alleviation and is a source of training for employment. Vocational training and development is considered as a solution for unemployment and organizations are spending huge amounts of money on VET in private and public sectors. The researchers believe that VET can solve workplace problems and is a source of skills and knowledge for the labor force. It is also observed that developing countries are spending huge amounts of money on VET but not meeting the local and international standards of skilled labor. Because of this fact, this is the dire need of time to work on the factors that are helpful in promoting quality vocational education and training.

Work based learning is an essential part of vocational learning in which an interrelation with the business community naturally relates to entrepreneurial learning (Jarvi, 2012). There is close cooperation between vocational schools and enterprises in Europe, but a gap still exists in entrepreneurship education (Jarvi, 2012). Unfortunately, very little research has been conducted on the education of entrepreneurship, in particular on vocational education (Pihie \& Bagheri, 2010) and there is dire need of time to include vocational entrepreneurship education in the vocational curriculum (Jarvi, 2012). Keeping in view the research conducted on VET, this research explains the most significant dimensions of VET: Curriculum Revision and Vocational Entrepreneurship

Education, Need Based Training, Interrelation with Industry, Employability, Assessment and Examination, Physical Resources and Trainee Selection. 


\section{Footnotes}

1 This paper is a part of a doctoral thesis which is being prepared by the author at the Faculty of Management, University of Warsaw, Poland under Tomasz Ochinowski's supervision.

\section{References}

Aldrich, C. (2002). Measuring success: In a postMaslow/Kirkpatrick world, which metrics matter? Online Learning, 6(2), 30-32.

Akomaning, E. et al. (2011). Internship in vocational education and training: stakeholders' perceptions of its organization. Journal of Vocational Education \& Training, 63(4), 575-592.

Allais, S. (2012). Will skills save us? Rethinking the relationships between vocational education, skills development policies, and social policy in South Africa. International Journal of Educational Development, 32, 632-642.

Ansari B. (2013). Development of Pakistan's Technical and Vocational Education and Training (TVET): An analysis of Skilling Pakistan Reforms. Journal of Technical Education and Training (JTET), 5(2).

Argüelles, A. \& Gonczi, A. (eds). (2000). Competency based education and training: $A$ world perspective. Balderas: Editorial Limusa S.A. de C.V. Grupo Noriega Editores.

Avis, J. (2012). The Ambiguities of Learning in the Knowledge Economy: Transformation, Innovation and Capital. Journal of Vocational Education \& Training, 64(1), 119-125.

Badaqir et al. (2011). Addressing the Gap in Saudi Arabia: does vocational education address the of private sector employees. Journal of Vocational Education and Training, 63(4), 551-556.

Bakah M.A.B. et al. (2011). Curriculum reform and teachers' training needs: the case of higher education in Ghana. International Journal of Training and Development, 16(1).

Baum, T. (2002). Skills and training for the hospitality sector: a review of issues. Journal of Vocational Education and Training, 54(3), 343-364.

Becker, G.S. (1962). Investment in human capital: A theoretical analysis. Journal of Political Economy, 70(5), 9-49.

Becker, G.S. (1975). Human capital. Columbia, USA: Columbia University Press.

Booth et al. (1996). Acquiring Skills: Market Failures, Their Symptoms and Policy Responses. Cambridge: Cambridge University Press.

Breen, R. (2005). Explaining cross-national variation in youth unemployment: Market and institutional factors. European Sociological Review, 21(2), 125-134.

Briga Hynes (1996). Entrepreneurship education and training, introducing entrepreneurship into non business disciplines. Journal of European Industrial Training, 20(8), 10-17.

Brockmann et al. (2008). Competence-based vocational education and training (VET): the cases of England and France in a European perspective. Vocations and Learning, 1(3), 227-244.

Brzinsky-Fay, C. (2007). Lost in transition? Labor market entry sequences of school leavers in Europe. European Sociological Review, 23(4), 409-422.

Budría, S. \& Telhado-Pereira, P. (2009). The contribution of vocational training to employment, job-related skills and productivity: evidence from Madeira. International Journal of Training and Development, 13(1), 53-72.

Busemeyer, M.R. (2009). Asset specificity, institutional complementarities and the variety of skill regimes in coordinated market economies. SocioEconomic Review, 7, 375-406.

Busemeyer, M.R. \& Trampusch, C. (2012). The comparative political economy of collective skill formation. In: M.R. Busemeyer \& C. Trampusch (eds), The political economy of collective skill formation (pp. 3-40). Oxford: Oxford University Press.

Cedefop. (2010). Learning outcomes approaches in VET curricula. A comparative analysis of nine European countries. Research paper no. 6. Luxembourg: Office for Official Publications of the European Communities.

Chalmers, D. \& Fuller, R. (1996). Teaching and Learning at University. London: Kogan Page.

Chen, J.-F. (2006) 工学结合教育模式可持续发展的理性期待 [A rational expectation for a sustainable development of a model of education which combined learning with working], 中国高教研究 [Chinese Higher Education Research], 8, 22-24.

Choy, S. \& Haukka, S. (2009). Industrial Attachments for Instructors in TVET Delivery. In: R. Maclean \& D. Wilson (eds.), International Handbook of Education for the Changing World of Work (pp. 1367-1382). Dordrecht: Springer Science \& Business Media B.V.

Clarke, L. \& Winch, C. (2007). Introduction. In: L. Clarke \& C. Winch (eds.), Vocational education: International approaches, developments and systems. London: Routledge.

Carmen et al. (2012). The relevance of education as a capital asset for economic development: references to the Romanian situation. Social and Behavioral Sciences, 46, 3582-3587.

Cornford, I. (1999). Rediscovering the importance of learning and curriculum in vocational education and training in Australia. Journal of Vocational Education \& Training, 51(1), 93-116.

Cort, P., Härkönen, A. \& Volmari, K. (2004). Professionalisation of VET teachers for the future. Thessaloniki: Cedefop. 
Cullen, R.B. (1997). Work skills and National Competitiveness: external benchmarks. Report No. 2: benchmarking Australian qualifications profiles for the Australian National Training Authority. Hawthorn: Performance Management Solutions.

De Graaf, W. \& van Zenderen, K. (2013). Schoolwork transition: The interplay between institutional and individual processes. Journal of Education and Work, 26(2), 121-142.

Divine et al. (2007). Required internships in marketing: Benefits, challenges and determinants of fit. Marketing Education Review, 17(2), 45-52.

Edmond A. et al. (2014). Strategies for revitalizing the implementation of entrepreneurship education in Technical, Vocational Education and Training (TVET) to enhance self-employment in Nigeria. British Journal of Education, 2(4), 50-62.

Enkuzena, S. \& Kliedere, E. (2011). Management training evaluation: a case study of a retail store Chain. Journal of Business Management, (4).

European Parliament and Council (2009). Recommendation of the European Parliament and of the Council of 18 June 2009 on the establishment of a European quality assurance reference framework for vocational education and training. Official Journal of the European Union, C 155, 01-10.

Farmer et al. (2004). A Model for Establishing Workforce Education and Development Programs in Developing Countries. The International Journal of Vocational Education and Training, 12(2).

Fayolle, A. (2010). Handbook of Research in Entrepreneurship Education, Volume 3: International Perspectives. Boston, MA: Edward Elgar.

Finch, C.R. and Crunkilton, J.R. (1999). Curriculum development in vocational and technical education: Planning, content and implementation. Boston: Allyn and Bacon (ISBN 0205279023), 5th Edition.

Grierson, J. \& Young, C. (2002). Technical and Vocational Education and Training in the $21^{\text {st }}$ Century: New Roles and Challenges for Guidance and Counselling. Paris: Division of Secondary, Technical and Vocational Education, UNESO.

Griffiths, T. \& Guile, D. (2003). A connective model of learning: The implications for work process knowledge. European Educational Research Journal, 2, 56-73.

Hansen, R.E. (1995). Teacher socialization in technological education. Journal of Technology Education, 6, 34-45.

Iqbal et al. (2014). Effectiveness of Performance Appraisal: An Integrated Framework. International Journal of Academic Reviews, 17(4), 510-533.

Iversen, T. \& Stephens, J.D. (2008). Partisan politics, the welfare state, and three worlds of human capital formation. Comparative Political Studies, 41(4/5), 600-637.
Jallah, M. (2004). UNESCO-UNEVOC - An international experts meeting "Learning for Work, Citizenship and Sustainability". The Experts Meeting in Bonn, Germany from 25 to 28 October 2004.

Jamshidi, A. \& Jamshidi, L. (2012). Evaluation of technical and vocational education in Iran. Social and Behavioral Sciences, 46(2012), 4070-4071. Journal of European Industrial Training, 26(5), 230-240.

Jing, X. (2011). Evolution and revolution in China's skill formation system. Journal of Education and Work, 24(5), 549-564.

Jones, C. (2010). Entrepreneurship Education: Revisiting Our Role and its Purpose. Journal of Small Business and Enterprise Development, 17(4), 500-513.

Jordan, T. (1989). Measurement and Evaluation in Higher Education. London: Falmer Press.

Jossberger, H. et al. (2010). The Challenge of Selfdirected and Self-regulated Learning in Vocational Education: A Theoretical Analysis and Synthesis of Requirements. Journal of Vocational Education \& Training, 62(4), 415-440.

Karbasioun et al. (2005). Informal Technical and Vocational Training Programs and Farming in the Province of Isfahan, Iran. Journal of International Agricultural and Extension Education, 12(2), 43-53.

King, K. (2009). Education, skills, sustainability and growth: complex relations. International Journal for Educational Development, 29, 175-181.

Leney, T. \& Green, A. (2005). Achieving the Lisbon goal: the contribution of vocational education and training. European Journal of Education, 40(3), 261-278.

Mahendran, M. (1997). Project-based assessment. In: M. Hargreaves (ed.), The Role of Assessment in Learning. Brisbane: Academic Staff Development Unit, Queensland University of Technology.

Matlay, H. (2008). The Impact of Entrepreneurship Education on Entrepreneurial Outcomes. Journal of Small Business and Enterprise Development, 15(2), 382-396.

McGrath, S. (2011). Where to now for vocational education and training in Africa? International Journal of Training Research, 9, 35-48.

McGrath, S. (2012). Vocational education and training for development: a policy in need of a theory? International Journal of Educational Development, 32(5), 623-631.

Margriet et al. (2014). Quantifying Stakeholder Values of VET Provision in the Netherlands. Vocations and Learning, 7, 1-19.

Maritz, A. \& Brown, C. (2013). Enhancing entrepreneurial self-efficacy through vocational entrepreneurship education programmes. Journal of Vocational Education \& Training, 65(4), 543-559. 
Middieton, J., Ziderman, A. \& Adams, A.V. (1993). Skills for Productivity: Vocational education and training in developing countries. New York: Oxford University Press.

Mincer, J. (1974). Schooling, experience and earnings. National Bureau of Economic Research. New York, U.S.A.

Moldovan, L. (2012). Innovative models for vocational education and training in Romania. Social and Behavioral Sciences 46(2012), 5425-5429.

Moskowitz, M. (2008). A Practical Guide to Training and Development: Assess, Design, Deliver and Evaluate. San Francisco, USA: John Wiley \& Sons.

Müller, W. \& Gangl, M. (eds.). (2003). Transitions from school to work: A European perspective. Oxford: Oxford University Press.

Mupimpila, C. \& Narayana, N. (2009). The role of vocational education and technical training in economic growth: a case of Botswana. International Journal of Education Economics and Development, 1(1), 3-13.

Mustafa et al. (2005). Enhancing Vocational Training for Economic Growth in Pakistan. The Pakistan Development Review, 44(4) Part II (Winter 2005), 567-584.

Nilsson, A. (2010). Vocational education and training - an engine for economic growth and a vehicle for social inclusion? International Journal of Training and Development 14(4), 251-274.

OECD (2001). Education at a glance 2001. OECD indicators. Paris: Organization for Economic Cooperation and Development (OECD).

OECD (2009). Learning for jobs. Reviews of vocational education and training. Initial report. Paris: Organization for Economic Co-operation and Development (OECD).

Oxtoby, R. (1997). Barriers to the Provision of Cost Effective Technical Education in Bangladesh. International Journal of Educational Development, 17(1), 91-99.

Palmer, R. (2009). Skills development, employment and sustained growth in Ghana: sustainability challenges. International Journal for Educational Development, 29, 133-139.

Pihie, Z. \& Bagheri, A. (2010). Entrepreneurial Attitude and Entrepreneurial Efficacy of Technical Secondary School Students. Journal of Vocational Education \& Training, 62(3), 351-366.

Ponis, S.T., Vagenas, G. and Koronis, E. (2009). Exploring the knowledge management landscape: a critical review of existing knowledge management frameworks. In: D. Harorimana (ed.), Cultural Implications of Knowledge Sharing, Management and Transfer: Identifying Competitive Advantage (pp. 1-25). Hershey, PA: IGI Global.
Powell, L. (2012). Reimagining the purpose of VET - Expanding the capability to aspire in South African Further Education and Training students. International Journal of Educational Development 32, 643-653.

Puyate, S.T. (2008). Constraints to the effective implementation of vocational education program in private secondary schools in Port Harcourt local government area. Asia-Pacific Journal of Cooperative Education, 9(2), 59-71.

Puyate, S.T. (2004, October). Manpower production for national development. Paper presented at the Nigerian Association of Teachers of Technology annual conference. Ibadan Oyo State, Nigeria.

Puyate, S.T. (2006, October). Facilities and the implementation of the national policies of education. Paper presented at the annual conference of the Nigerian Association of Teachers of Technology. Umunze, Anambra State, Nigeria.

Russ-Eft, D. (2002). A typology of training design and work environment factors affecting workplace learning and transfer. Human Resource Development Review, 1, 45-65.

Schaap, H. et al. (2012). Students' Learning Process during School Based Learning and Workplace Learning in Vocational Education: A Review. Vocation and Learning, 5, 99-117.

Scherer, S. (2005). Patterns of labor market entry Long wait of career instability? An empirical comparison of Italy, Great Britain and West Germany. European Sociological Review, 21(5), 427-440.

Schultz, T.W. (1961). Investment in human capital. New York, USA: JSTOR.

Scott, D. (1997). The language of assessment. In: M. Hargreaves (ed.), The Role of Assessment in Learning. Brisbane: Academic Staff Development Unit, Queensland University of Technology.

Shaw, G. (1999). 'European standards' in vocational education and training (VET): what are they and who wants them. European Journal of Education, 34(2), 137-152.

Sower, S. (1971). Trends in technical education development in West Africa. Journal of Education, 2, 35-40.

Spielhofer, T. and Sims, D. (2004). Modern apprenticeships in the retail sector: stresses, strains and support. Journal of Vocational Education and Training, 56(4), 539-558.

Stanton, G. \& Bailey, B. (2001). VET under review in England: trends and developments. European Journal of Education, 36(1), 7-22.

Streeck, W. (2012). Skills and politics: General and specific. In: M.R. Busemeyer \& C. Trampusch (eds.), The political economy of collective skill formation (pp. 317-352). Oxford: Oxford University Press. 
Swanson, R.A. (1995). Human resource development: Performance is the key. Human Resource Development Quarterly, 6(2), 207-213, Summer.

Sung, J. (2010). Vocational education and training and employer engagement: an industry-led sectoral system in the Netherlands. International Journal of Training and Development, 14(1), 16-31.

Tassmeer, M. \& Harris, D. (1992). Analyzing the instructional setting: Environmental analysis. London: Kogan page.

Thomas, A.B. (2004). Research Skills for Management Studies. London: Routledge.

Tilak Jandhyala, B.G. (2002). Vocational education and training in Asia. In: J.P. Keeves \& R. Watanabe (eds.), The Handbook on Educational Research in the Asia Pacific Region. Kluwer Academic Publishers.

Tranfield, D., Denyer, D. \& Smart, P. (2003). Towards a methodology for developing evidenceinformed management knowledge by means of systematic review. British Journal of Management, 14, 207-222.

Tynjälä, P. (2008). Perspectives into learning at the workplace. Educational Research Review, 3, 130-154.

Tynjälä, P. (2009). Connectivity and transformation in work-related learning: Theoretical foundations. In: M.-L. Stenström \& P. Tynjälä (eds.), Towards integration of work and learning: Strategies for connectivity and transformation (pp. 11-37). Dordrecht: Springer.

UNESCO (2004). International Experts Meeting "Learning for Work, Citizenship, and Sustainability". UNESCO, Bonn-Germany.

Van den Akker, J.J.H. (2003). Curriculum Perspectives: An Introduction. In: J.J.H. van den Akker, W. Kuiper \& U. Hameyer (eds.), Curriculum Landscapes and Trends (pp. 1-10). Dordrecht: Kluwer.

Virtanen A., Tynjälä, P. \& Eteläpelto, A. (2014). Factors promoting vocational students' learning at work: study on student experiences. Journal of Education and Work, 27(1), 43-70.

Vogtenhuber, S. (2014). The impact of within country heterogeneity in vocational specificity on initial job matches and job status. Journal of Vocational Behavior, 8, 374-384.

Westerhuis, A. (2007). The role of the state in vocational education: A political analysis of the history of vocational education in the Netherlands. In: L. Clarke \& C. Winch (eds.), Vocational education: International approaches, developments and systems. London: Routledge.

Wolbers, M.H. (2007). Patterns of labor market entry a comparative perspective on school-to- work transitions in 11 European countries. Acta Sociologica, 50(3), 189-210. 